\section{Could the inhalation of cadmium and other metals in addition to textile dust inhalation account for the observed increased risk of rheumatoid arthritis in textile workers?}

We read the report of Too et $a l^{1}$ with interest. We support the hypothesis of gene-environment interaction triggering an autoimmune response to citrullinated proteins in lung tissue, and feel this study strengthens the concept of inhalation of workplace dust or fumes stimulating rheumatoid arthritis (RA) development.

It has been hypothesised that cadmium inhalation within dust or fumes may trigger RA. ${ }^{2}$ This hypothesis noted that patients with RA are significantly more likely to work in specific occupations associated with increased cadmium exposure as a result of inhalation of various dusts or fumes. Textile manufacture may well be added to this as an important source of cadmium. A review article of trace metal pollution in soils affected by industrial processes highlighted that the textile industry was associated with the discharge of very high levels of cadmium. ${ }^{3}$ Indian $^{4}$ and Bangladeshi ${ }^{5}$ soils around textile plants demonstrated cadmium concentrations of $83.6-164 \mathrm{mg} / \mathrm{kg}, 28-56$ times higher than European Union recommended levels. ${ }^{6}$ Cadmium-based pigments are used in the dyeing and finishing of technical textiles and include colour index pigment yellow 35 , orange 20 and red 108 . $^{7}$

In Cornwall (UK), we undertook a provisional study of the occupations undertaken prior to the diagnosis of seropositive RA in women who had not smoked for 20 years before disease onset $(n=49)$. Via telephone survey, it was noted that the third most common occupation was rubber and plastics processing, an occupation associated with cadmium inhalation as cadmium was used as both a pigment for colouring and a stabilising agent. $^{8}$ Further, cadmium-associated occupations ${ }^{2}$ were noted. Cadmium exposure-related manufacturing occupations made up $22 \%$ of the study group's occupations. Interestingly, only $4 \%$ of the female Cornish workforce are employed in the manufacturing sector. ${ }^{9}$ Cadmium in micromolar concentrations is associated with a proinflammatory state, ${ }^{10}$ and high dose cadmium administration to Wistar rats has been shown to exacerbate collagen-induced arthritis disease development, demonstrating immunohistochemical expression of proinflammatory cytokines, confirmed with histopathological analysis. ${ }^{11}$ In addition to the potential immunological sequelae of dust or fume inhalation per se, the distinct pathological consequences of cadmium inhalation should be considered, as smoking studies have demonstrated dramatically higher serum cadmium levels from inhalation. ${ }^{12}$ As part of an inhaled dust or fume mix, cadmium has the potential to directly enter the joint via the systemic circulation and initiate the rheumatoid process, in addition to local effects in the lung.

Smokers also have raised blood levels of chromium and lead. ${ }^{12}$ A review of the current status of the Malaysian textile industry wastewater management highlights that there are heavy metal content in different dye classes such as copper, chromium, lead, manganese, cadmium, nickel and zinc. ${ }^{13}$ We would suggest that quantification of bodily levels of relevant metals is an important consideration for future studies investigating RA pathogenesis in textile dust exposure.

Dan Murphy, Aishwarya Mathew, Benjamin James, David Hutchinson

Rheumatology Department, Royal Cornwall Hospitals NHS Trust, Royal Cornwall Hospital, Cornwall, UK

Correspondence to Dr Dan Murphy, Rheumatology Department, Royal Cornwall Hospitals NHS Trust, Royal Cornwall Hospital, Truro, Cornwall TR1 3LJ, UK; daniel.murphy8@nhs.net

Citation: Too CL, Muhamad NA, Ilar A, et al., MyEIRA Study Group. Occupational exposure to textile dust increases the risk of rheumatoid arthritis: results from a Malaysian population-based case-control study. Ann Rheum Dis 2015.

Competing interests None declared.

Provenance and peer review Not commissioned; internally peer reviewed.

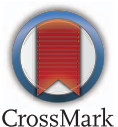

To cite Murphy D, Mathew A, James B, et al. Ann Rheum Dis 2016;75:e30.

Received 19 January 2016

Accepted 21 January 2016

Published Online First 9 February 2016

Ann Rheum Dis 2016;75:e30. doi:10.1136/annrheumdis-2016-209228

\section{REFERENCES}

1 Too CL, Muhamad NA, Ilar A, et al. MyEIRA Study Group. Occupational exposure to textile dust increases the risk of rheumatoid arthritis: results from a Malaysian population-based case-control study. Ann Rheum Dis 2015; Published Online First 17 Dec 2015. doi.org/10.1136/annrheumdis-2015-208278

2 Hutchinson D. Cadmium, one of the villains behind the curtain: has exposure to cadmium helped to pull the strings of seropositive rheumatoid arthritis pathogenesis all along? Int J Rheum Dis 2015;18:570-3; quiz 574-6.

3 Kabir E, Ray S, Kim KH, et al. Current status of trace metal pollution in soils affected by industrial activities. Sci World J 2012:2012:196705.

4 Deepali KK, Gangwar K. Metals concentration in textile and tannery effluents, associated soils and ground water. NY Sci J 2010;3:82-9.

5 Kashem A, Singh BR. Heavy metal contamination of soil and vegetation in the vicinity of industries in Bangladesh. Water Air Soil Pollut 1999;115:347-61.

6 European Community Directive. Protection of the environment, and in particular of the soil, when sewage sludge is used in agriculture. J Eur Comm 1986;181:6-12.

7 Gulrajani M. Advances in the dyeing and finishing of technical textiles. Cambridge, UK: Woodhead Publishing Ltd, 2013:120-1.

8 European Chemicals Agency. Cadmium and cadmium compounds in plastics preparatory report, 2012. https://echa.europa.eu/documents/10162/13641/ cadmium_in_plastics_prep_report_en.pdf (accessed 19 Jan 2016).

9 Office for National Statistics. 2011 Census: an overview of the headline figures for Cornwall, 2012. p20. https://www.cornwall.gov.uk/media/12900814/ 2011-Census-An-Overview-of-the-Headline-Figures-for-Cornwall.pdf (accessed 19 Jan 2016).

10 Olszowski T, Baranowska-Bosiacka I, Gutowska I, et al. Pro-inflammatory properties of cadmium. Acta Biochim Pol 2012;59:475-82.

11 Ansari MM, Neha, Khan HA. Effect of cadmium chloride exposure during the induction of collagen induced arthritis. Chem Biol Interact 2015;238:55-65.

12 Bernhard D, Rossmann A, Wick G. Metals in cigarette smoke. IUBMB Life 2005;57:805.

13 Pang YL, Abdullah AZ. Current status of textile industry wastewater management and research progress in Malaysia: a review. Clean Soil Air Water 2013;41:751-64. 